\title{
ケーブル金物の設計法に関する基礎的研究 \\ BASIC STUDY ON DESIGN METHOD FOR METAL FITTING OF CABLE
}

\author{
斎藤公男*, 岡田章** \\ Masao SAITOH and Akira OKADA
}

\begin{abstract}
Cable made by bundling fine high tensile strength materials has flexibility and the strength to weight ratio is high. Also a great advantages of cable is that there is no limit to the length of members from a manufacture and a transportation view point. When applying cables to structures, it is effective to use the "middle clamp jointing method" in order to make the best economical use of both the properties of cables and their advantages over other materials. This method, in which other members are connected to the middle part of a cable, has the most distinctive characteristic that a single long cable can be used continuously without being cut at the clamping part unless absolutely necessary. This paper proposes a design method for a metal fittings for the cable structures by carrying out both experiments and analyses on the following items.
\end{abstract}

(1) Principal factors for the design of metal fittings used for the middle clamp jointing.

(2) A method for establishing an appropriate safety factors for the metal fittings of cable.

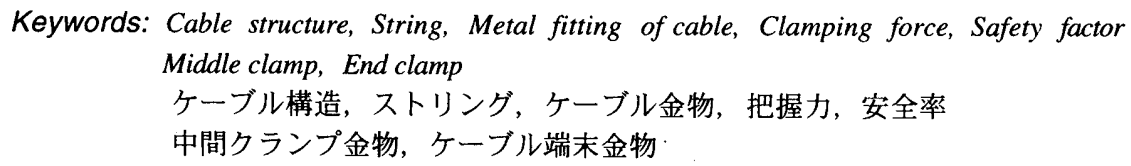

\section{1.はじめに}

近年我国では、張弦梁構造 ${ }^{3)}$ 4) やガラスファサードの支持構造 5 )

6) 等に見られるようにケーブルを用いた建築物が増加する傾向に ある。これは特有の性質（柔軟性、長尺性、高強度）を有するケー ブルを、空間構造や大スパン構造のストリング7) 8) として使用し た場合、構造・施工法等の面で合理的な解を与えると共に、魅力的 な構造表現や造形的自由度が可能となることが社会的に認知されつ つある結果とも捉えられよう。

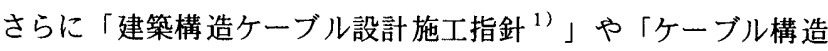

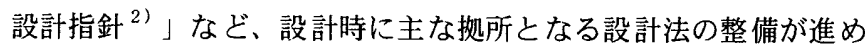
られていることも一因であろう。これらは、機能、形状、規模、構 成、荷重面で多岐にわたる建築のケーブル構造に対して、構造計画 や設計に関する基本的な考え方を示したものと評価できる。

しかしこのような状海にも関わらず、我国の建築物に対するケ一 ブルの適用例は、欧米に比べるとかなり少なく、ストリングとして はロッドが一般的に使用されているのが現状である。強度に対する ケーブル本体のコストはロッドと大差ないこと、強度や運搬面にお いてケーブルがロッドに比べると卓抜した性能を有することを考虑 すると、ストリングとしてケーブルが一般的に使用されていない我 国の状況は、特殊とさえ思える。
この原因としては、ケーブルに対する法的規制の存在以外に、ケー ブルの設計法と施工に関する技術的蓄積、特にディテール設計に関 わるデータが未整備であることがあげられる。溶接が不可能なケー ブルでは、ケーブル相互あるいはケーブルと他部材との接合部には、 特殊な接合方法の考案や設計思想が必要となるため、後者のディテー ル設計の内、特に接合部に関する設計データの不足はケーブルの普 及を妨げる大きな要因と考えられる。例えば現行の接合部の設計法 は、車輭荷重等を対象とした橋梁分野で蓄積された太径ケーブルの 材料データ ${ }^{9 （ 10)}$ に基づいて構築されたものであり、細径ケーブル を用いた構造が大部分を占める建築物に適用した場合、接合部など の規模が大きくなるなど、意匠面・コスト面でケーブルの適用を躊 躇させる問題が発生しがちである。さらに著者らの知る限りでは、 この建築物への適用を念頭に置いた接合部に関する研究は未だ報告 されていないのが現状である。このように、建築の要求機能に対応 した、材料データの蓄積や設計法の確立が望まれている。 ケーブル構造の接合部は次の三種類に大別できる（図 1）。

(1)ケーブル端末部 : ケーブルの端末には、ソケット止めや圧縮止 めなどのケーブルと一体化した金物が一般に使用される。

(2)ケーブル中間部・屈曲部やケーブル交差部 : これらの接合部で はケーブルを切断しないで連続使用するため、ケーブルと分離
本諭文の一部は文献14)～16)に報告している。

*日本大学理工学部建築学科 教授. 工博

** 日本大学理工学部建築学科 助手. 工修
Prof., Dept. of Architecture, Nihon University, Dr. Eng. Research Assoc., Dept. of Architecture, Nihon University, M. Eng. 

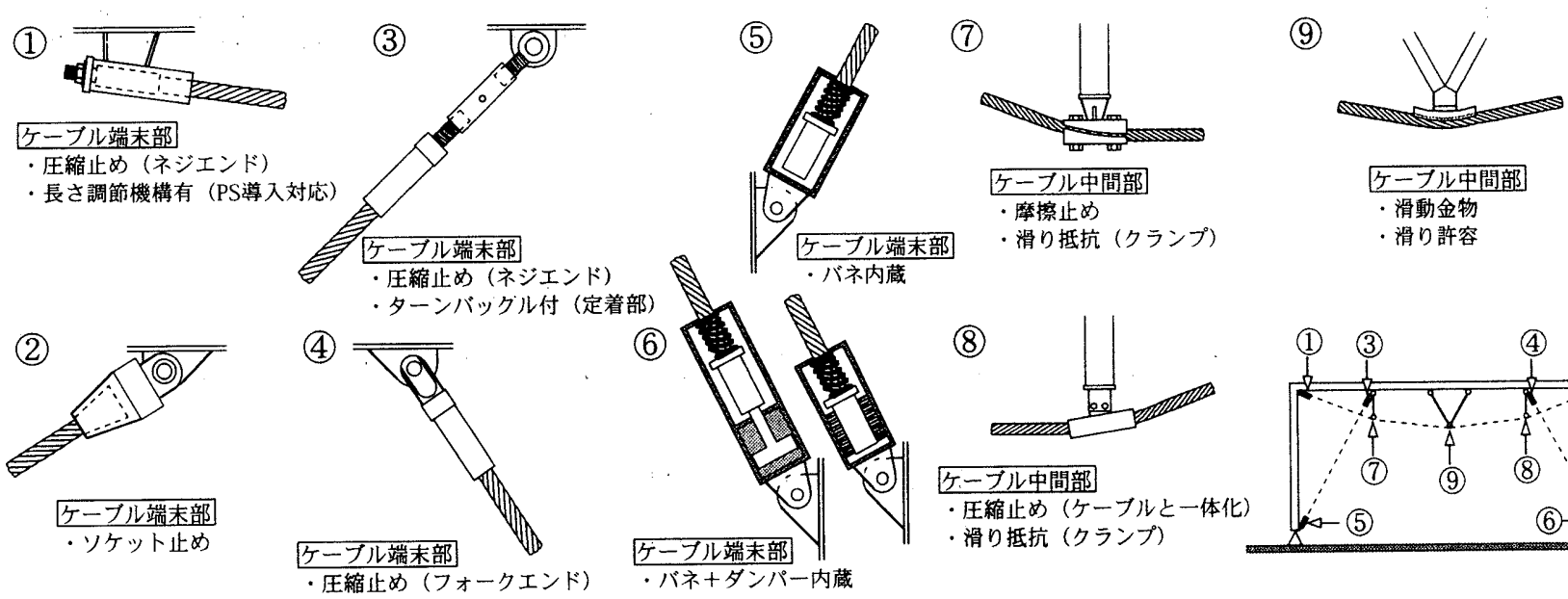

図1 ケーフルル構造の接合部の種類

した摩擦止めの金物または一体化した圧縮止めの金物を使用し、

クランプ接合（ケーブルを固定）あるいは滑動接合（ケーブル

の滑りを許容）により、安定した力の釣合いを形成する。

(3)定着部か) : ケーブルと支持構造などとの間に設けられるイン ターフェースとしての部位を指す。

これらの接合部の設計時における特有の課題を以下に示す。

(1)初期張力（PS）導入方法への配慮

(2)支持架構等の製作・施工誤差や巻き取り・運搬に伴うケーブル

長の微小変化への対応

(3)ケーブル張力の不釣合力（接合部の両側に生じるケーブル張力

の差）に対する抵抗

(4)張力保持機構・隇哀機構の組込み

(5)妥当性のある安全率の設定

(6)コストと要求性能のバランスを考虑した設計法の確立

これらの課題を分析すると、ケーブルと一体化あるいは分離した 形で、ケーブル本体に接触して取り付けられる金物、すなわち「ケー ブル金物」の設計と大きく関わっていると考えられる。

本論では、以上の諸点を踏まえて、ケーブル中間部に用いられる 摩擦止め方式のクランプ接合（以下「中間クランプ接合」）とケー ブル端末部の接合を対象として、

(1)中間クランプ接合に用いられる金物（以下〔中間クランプ金物」） の設計のための主要因子

(2)中間クランプ金物とケーブル端末部の金物（以下「ケーブル端 末金物」）等のケーブル金物の適正な安全率の設定の方法

について、実験と解析の両面から検討を加え、ケーブル金物の設計 法について提案を行うものである。ここで11の「中間クランプ接合」 は、一本のケーブルをできるだけ長い状態で連続的に使用するため に不可欠な接合であり、ケーブルの特性や経済性を発揮することを 指向した基本的な方式である。

本論では、まず(1)において中間クランプ金物の設計時の重要な因 子である把握力、摩擦保数、軸力低下係数、許容側圧等の設定值の 妥当性の評価のために、以下の項目について検討を行った。

(1)中間クランプ金物の把握性能の評価（滑動実験・付加荷重案験）

(2)中間クランプ金物における滑りの発生がケーブル強度の低下に 及ぼす影響（引張疲労試験）

(3)同様の滑りの発生が構造システムに及ぼす影響（解析）
(4)側圧がケーブル強度の低下に及ぼす影響（引張（疲労）試験） 次に(2)においては、上記(1) (4)で得られた性能に基づいて適正な 安全率の設定のための基本的な考元方を提案した。これらは構造シ ステム全体の安全率とケーブル金物の安全率の整合性を図ることを 目的としたものである。本論では、張弦梁構造を対象として終局状 態に着目した中間クランプ金物およびケーブル端末金物の設計法の 提案を行い、ケーブル金物の縮小化と合理化の可能性を示す。

\section{2. 中間クランプ金物の把握カの実験}

\section{1 中間クランプ金物の要求機能}

ケーブルを建筑物に適用する際、ケーブル特有の性質（柔軟性、 長尺性、高強度)や有利性を経済的に発揮させるためには、以下の 諸点に注意を払う必要がある。

・ケーブルをできるだけ長い状態で使用する。

・ケーブル長の調整を行う䈏所を少なくする。

・少ない匴所、かつ小さな力で、所定のPS量を導入できる。

・ケーブル金物の数の削減や：機構の簡素化を図る。

これらを踏まえると、ケーブル構造においては一本の長いケーブ ルの中間部に他の部材を接合する方式（中間クランプ接合）の適用 が有効となる。この中間クランプ接合部に用いられる中間クランプ 金物には、以下の機能が要求される。

・クランプ部でケーブルを切断しない。

・接合部の構成部材や機構はできるだけ単純なものとする。

・クランプ部の両側のケーブルの張力差 (以下「滑動力」)によ り生じる滑りに抵抗する。

図 2 に我国で最近のケーブル構造の事例を取り上け゚、設計荷重時 に中間クランプ部に生じる滑動力を示す。張弦トラス ${ }^{1121}$ 、テン セグリック・トラス ${ }^{(3)}$ といったトラス抵抗系を有する構造システ ムにおいては、滑動力（T1-T2）が大きくなる傾向がある。この ため中間クランプ部分の設計においては設計用の顝力の評価、必 要把握力の設定、抵抗メカニズムの評価等が特に重要となる。

\section{2 中間クランプ金物の構成}

前述したように、中間クランプ金物には滑動力に抵抗する性能 （把握力）が求められる（図 3)。クランプ金物の設計時に目標と される把握力の大きさGoは、想定される骬動力の大きさ $\Delta T$ 以上 に設定され、両者の関係は安全率レを用いて次式で表される。 


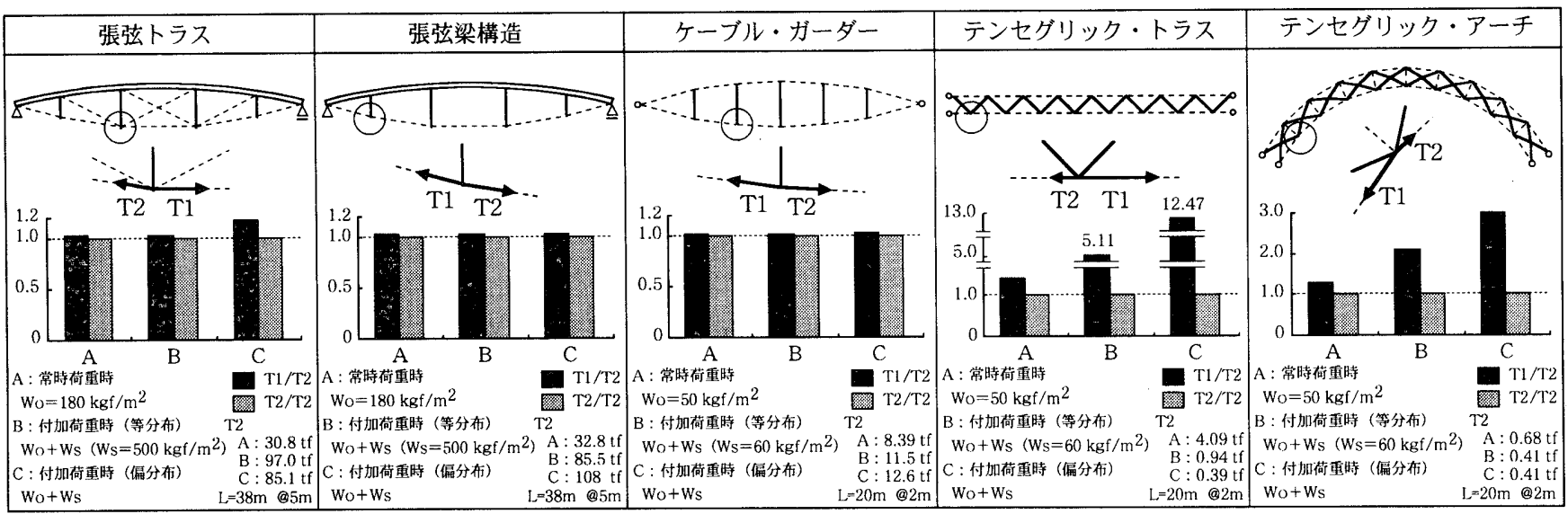

図 2 ケーブル構造の中間クランプ部に生じる滑動力の大きさの比較

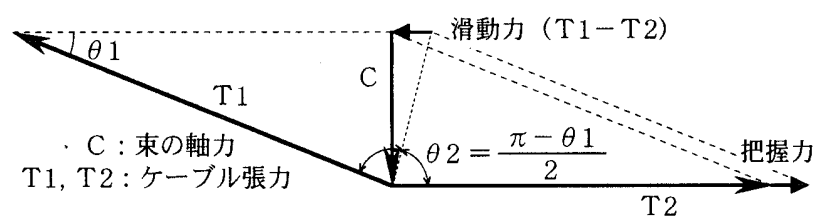

図 3 ケーブル張力と滑動力

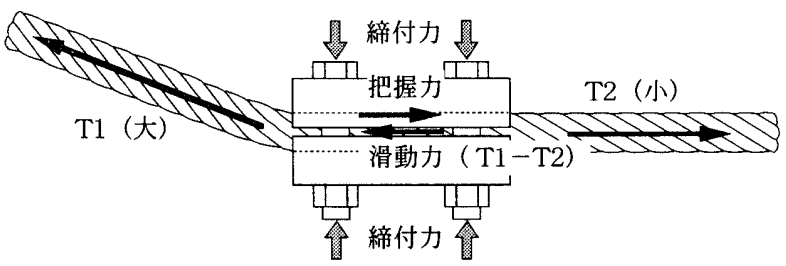

（a）直線状金物の例

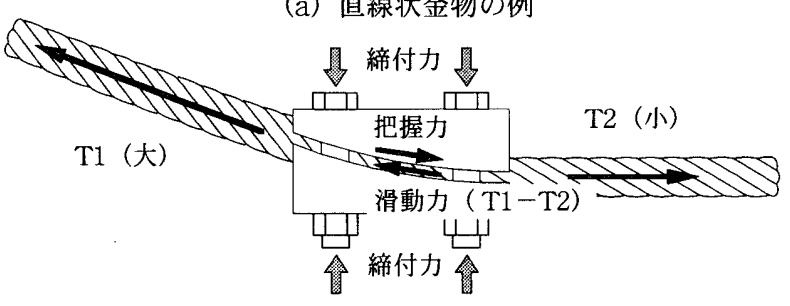

(b) 曲率付金物の例

図 4 中間クランプ接合

$\mathrm{GO}=\nu \times \Delta \mathrm{T}$

中間クランプ金物に一般的に採用される摩擦止め方式は、ケーブ ルを両側から挟み込む二枚のプレートと、両プレートを接続するボ ルトにより基本的に構成され、把握力はボルトによりケーブル軸の 直交方向に加えられた圧縮力（締付力）に起因する摩擦により得ら れる（図 4）。中間クランプ金物の実例を図 5 に示す。中間クラン プは比較的曲げ剛性の高いプレートを使用したものと、プレートの 弾性を期待したものの二種類に大別できるが、本論では我国の建築 分野で適用例が多い前者を対象とする。

\section{3 現行の中間クランプ金物の設計手法と問題点}

中間クランプ金物の設計は、通常以下の順序で行われる。

(1)想定される滑動力 $\Delta \mathrm{T}$ の算定。

(2) $\Delta \mathrm{T}$ に抵抗するために必要な把握力（Go）の設定（図6 (a)式）。 (3)Goを生じさせるためのボルト締付力（N）の設定（図6(b)式。 (4)締付力を生じさせるために必要なボルト径と本数の設定。

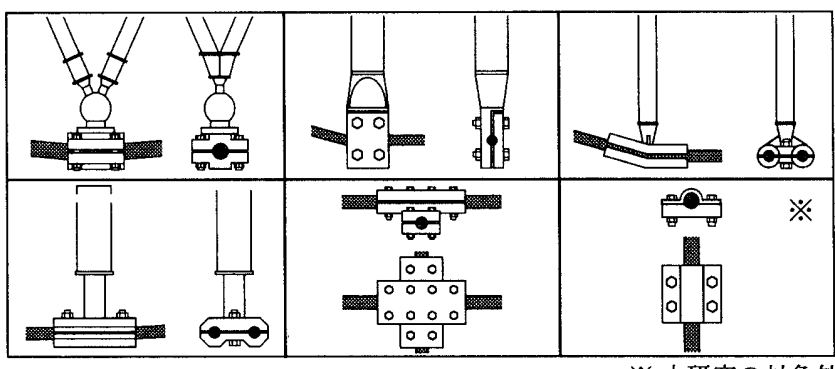

※ 本研究の対象外

図 5 中間クランプ金物の一例

\begin{tabular}{|lll}
\hline $\begin{array}{l}\text { 《設計用把握カ : } G O 》 \\
\text { 《必要締付カ }: N 》\end{array}$ & $G O=\nu \Delta T$ & $--(\mathrm{a})$ \\
& $N=\frac{G O}{m \mu k}$ & $--(\mathrm{b})$ \\
《必要クランプ長さ $: L 》$ & $L=\frac{1}{f p d} N$ & -- (c)
\end{tabular}

Go : 設計用把握力（滑り耐力）

$\nu$ : 安全率（長期 $\nu=3$ 、短期 $\nu=2.2$

$\Delta T:$ 滑動力 $(=|\mathrm{T} 1-\mathrm{T} 2|)$

$m$ : 締付部形状により定まる形状係数（推奖値 $m=2$ )

$\mu$ : 摩擦係数 (スチール $\mu=0.15$ )

$k$ : 軸力低下係数（通常 $k=0.7$ )

$f p ：$ ケーブルの許容側圧

$d ：$ ケーブル径（金物と接触するケーブルの幅）

図 6 クランプ金物設計式（現行） 18)

(5)許容側圧（fp)に基づくプレート長の算定（図 6 (c)式）。 (6)プレートの曲げ耐力に基ブくプレート厚さの算定。

これらのうち(2)(3)の把握力と締付力の設定は(4)～(6)の算定の基本 となり、クランプ金物の大きさを決定するため、意匠面やコスト面 に大きく関わる。しかしながら現行の設計法では、特に安全率 $(\nu)$ と許容側圧（fp）の二つの值に関して設定根拠が明らかにされてお らず、妥当性のある適正值の設定が望まれているのが現状である。

\section{3. 中間クランプ金物の把握力の評価－滑動・付加荷重実験 \\ 3.1 実験概要}

本実験は、ケーブル種、クランプ部における折れ角、金物の形状 等が中間クランプ金物の把握力に及ぼす影響を定量的に評価し、設 計用把握力の設定に関わる基本資料を得ることを目的としている。

実験はクランプ金物の把握性能に着目した「滑動実験」と、付加 荷重時のクランプ金物の性状を評価するための「付加荷重実験」を 
実施した。それぞれの実験装置を図 7 と図 8 に示す。試験体は、実 際のケーブル構造で標準的に採用されている規模・形状のものを原 寸で使用することとした（図 $9 \cdot 10 ） 。$ 実験パラメータを表 1 に 示す。使用金物の内、「口元のみR」は、ケーブルに折れ角が発生 する部分の溝部のみ曲面加工したものであり、クランプ金物の標準 化と簡素化を意図したものである。

滑動実験はケーブルに初期張力（1.0tf）を発生させた状態で、 束下部のプレートによりケーブルをクランプし、ケーブルの片端部 のジャッキで張力（T1）を導入することで滑動力を発生させた （図 7）。滑動力の大きさは、クランプ両側の張力（T1、T2）を ロードセルによって測定することにより評価した。一方、付加荷重 実験は初期張力の発生後、束内部に別途設置したジャッキで束を伸 長させ、ケーブルに下向きの荷重を加えた（図 8)。

なお、ケーブル張力は両端のロードセル、プレートを締付けるボ ルトの軸力はボルトに埋め込んだ歪ゲージ、ケーブルのクランプ部 における滑り量は高感度変位計によりそれぞれ測定を行った。

\section{2 滑動実験結果および考察}

図11a）b）に、ケーブルの折れ角が $0{ }^{\circ}$ の滑動実験結果を、締 付力（ボルト 4 本の軸力和の目標値）をパラメータにして示す。図 a）の縦軸は、クランプに生じる滑動力を締付力で無次元化した值 であり、横軸はクランプ金物からのケーブルの滑り出し量を示す。

グラフよりケーブルが最初に滑り出す無次元化骬力は 0.25 動力 0.3 とほぼ定值を示しており、クランプ金物の締付力と把握力の 間の線形関係が確認された。この值は規準式の推奖值 $\mathrm{m} \mu=0.3$ (cf. 図6 (b)式) とも良い一致を示している。またケーブルの初 期滑りの後、把握力が大きくなる傾向も得られている。この把握力 の增加量は締付力と共に大きくなる傾向があることから、ケーブル の締付によるケーブル径の減少に起因していると想定できる。すな わち滑り発生時に、クランプのケーブル挿入部分で、締付けにより 生じたくびれが一種の楔のように機能するものと考えられる。本論 では、このことによりプレートの締付により発生する摩擦力以上に 滑り抵抗力が増加する効果を「楔効果」と呼ぶ。

$\mathrm{T} 1$ の張力の増大に伴い、ボルト軸力はT2側に比べてT1側の方が 小さくなる傾向が得られている。またこの傾向は、締付力が大きく なるほど顕著に現れており（図11c）、上記楔効果の影響と考えら れる。締付力（ボルト軸力の合計值）はケーブルの短期許容引張力 （ $\mathrm{T}=7.86 \mathrm{tf} ）$ 時において最大約 $94 \%$ まで減少しているが（N= 16tf）、規準の推奨値（ $\mathrm{k}=0.7 ）$ の.34倍に留まっている。

図12に締付力が一定（目標值：4tf）時の結果を、ケーブルの折 れ角 $\theta$ をパラメータにして示す。 $\theta$ が大きくなるにつれて把握力が 大きくなる傾向が得られている。これは初期状態の束を圧縮する力 に伴う存在摩擦力の効果と評価できる。

図13は締付力が一定（目標值：8tf、 $\theta=0^{\circ}$ ）時の結果を、ケ一 ブル種をパラメータにしてロッドの結果と共に示したものである。 スパイラルの場合、楔効果に起因する把握力の増加量は、ストラン ドと同程度現れている。一方、締付による径の縮小が微小なロッド ではこの性状は見られない。

図14に締付力の目標值が $4 \mathrm{tf}$ 、折れ角 $\theta$ が $20^{\circ}$ の時の結果を、 クランプ金物の形状をパラメータにして示す。ロ元のみR、大きな $\mathrm{R}$ とも把握力に関して顕著な差異はみられないことから、ケーブル の柔軟性を利用した「口元のみR」の適用性が確認され、クランプ

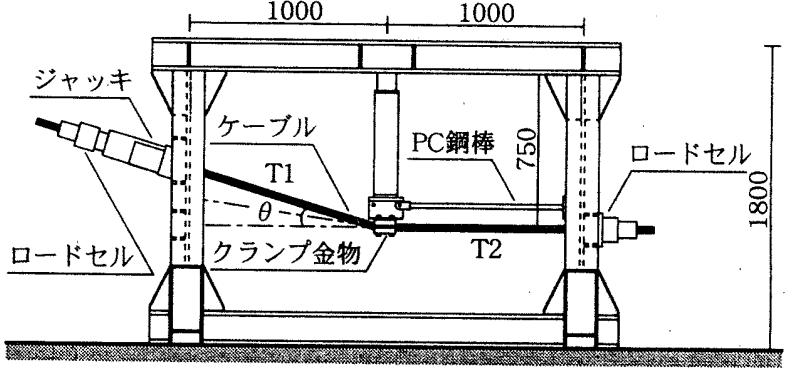

図 7 実験装置（滑動実験）

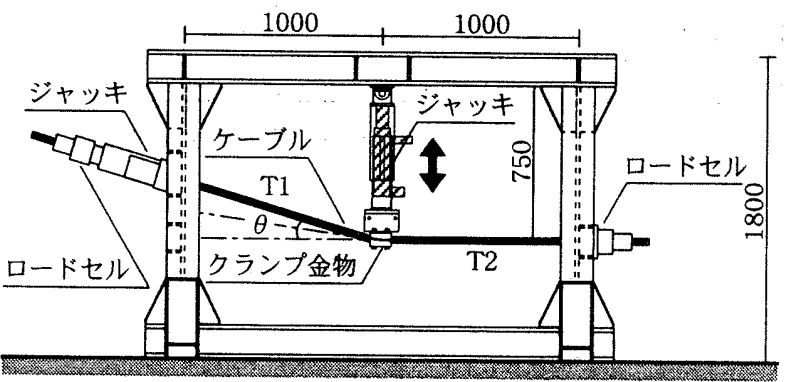

図 8 実験装置（付加荷重実験）

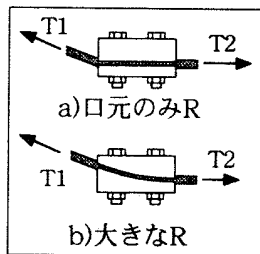

\begin{tabular}{|c|c|c|c|c|}
\hline ケープ ルの種類 & $\begin{array}{l}\text { 金物の } \\
\text { 形状 }\end{array}$ & $\begin{array}{l}5-7^{5} \| \text { } \\
\text { 折れ角 }\end{array}$ & $\begin{array}{l}\text { 金物の } \\
\text { 締付力 }\end{array}$ & 試驗体数 \\
\hline \multirow{2}{*}{$\begin{array}{l}\text { 잧․ } \\
7 \times 19-7^{\circ} \\
\$ \times 16\end{array}$} & \multirow{2}{*}{ 大きなR } & $20^{\circ}$ & $4.8(\mathrm{tf})$ & \multirow{5}{*}{$\begin{array}{l}7 \text { 体 } \\
(4,8 \mathrm{tf}) \\
3 \text { 体 } \\
(16 \mathrm{tf})\end{array}$} \\
\hline & & $10^{\circ}$ & $4,8,16(\mathrm{tf})$ & \\
\hline \multirow{3}{*}{ 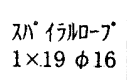 } & \multirow{3}{*}{ 口元のみR } & $20^{\circ}$ & $4,8(\mathrm{tf})$ & \\
\hline & & $10^{\circ}$ & $4,8,16(\mathrm{tf})$ & \\
\hline & & $0^{\circ}$ & $4,8,16(t \mathrm{f})$ & \\
\hline
\end{tabular}

図 9 金物形状

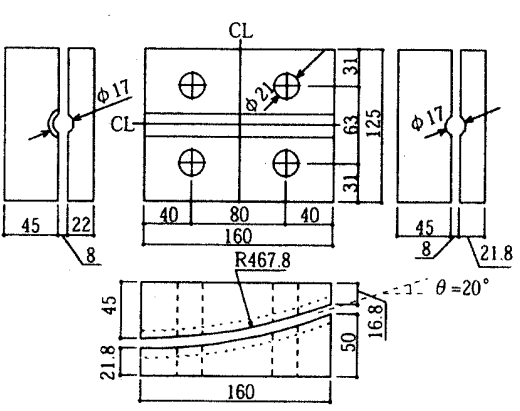

図10 金物詳細図

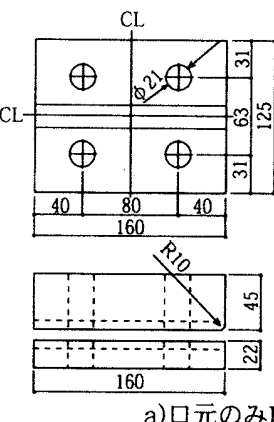

a)口元のみR

金物の標準化や簡素化につながると期待できる。

\section{3 楔効果の評価}

前述した初期滑りの発生後の把握力の増加、すなわち楔効果を適 正に評価することは、設計の合理化につながる重要な項目と考えら れる。ここでは楔効果を評価するための基本式を提案する。クラン プ部の締付力によりケーブル径が減少した状況を表わしたモデル （図15）を用いると、当該部分の釣合条件から、初期滑り発生時 の初期把握力Goに対する楔効果により増加した把握力Guの比 $\beta$ が 次式のように求まる。

$$
\beta=\frac{\mathrm{Gu}}{\mathrm{Go}}=\frac{\tan \alpha}{\mu}+1
$$

$\alpha$ は揳効果によりケーブルに作用する玨縮力の傾斜角を、プレ一 卜面の法線とのなす角で表わしたものである。ここでル（摩擦係数） として0.15 (スチール) を用いて、さらに全実験結果より得られ た $\beta$ の值（表 2 ）より $\alpha$ を算定するとストランドで $7.9 \sim 14.1^{\circ}$ 、 

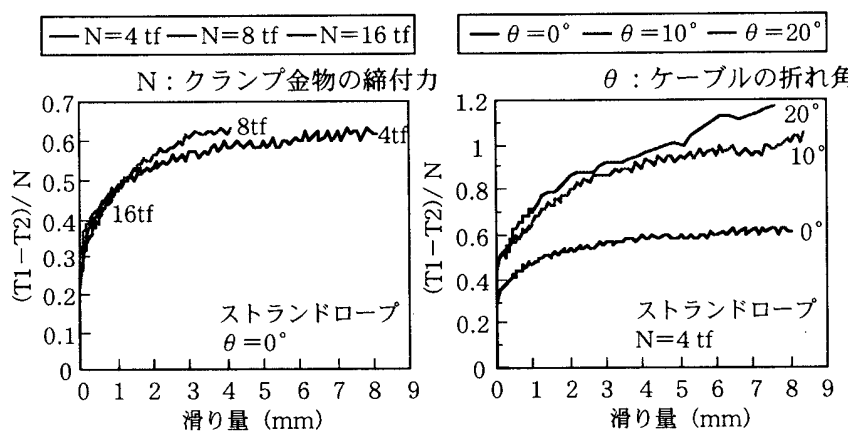

a) 無次元化滑動力と滑り量の関係 a)無次元化滑動力と滑り量の関係

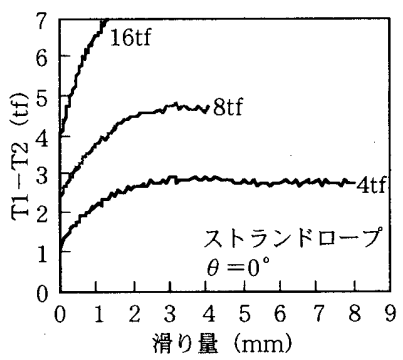

b)滑動力と滑り量の関係

※ 4tf-1はT1側のボルト軸力 2 本の合 計、4tf-2はT2側の同値を示す。

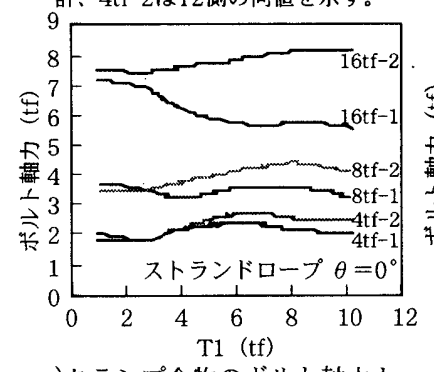

c)クランプ金物のボルト軸力と ケーブル張力（T1）の関係

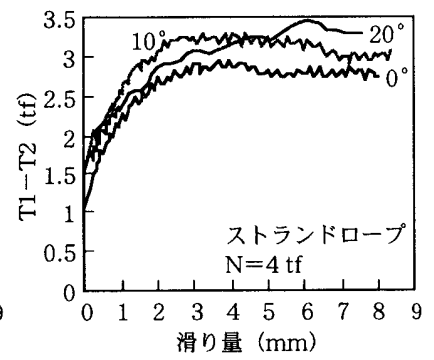

b)滑動力と滑り量の関係 ※ 0-1はT1側のボルト軸力 2 本の合計、 0 -2はT2側の同値を示す。

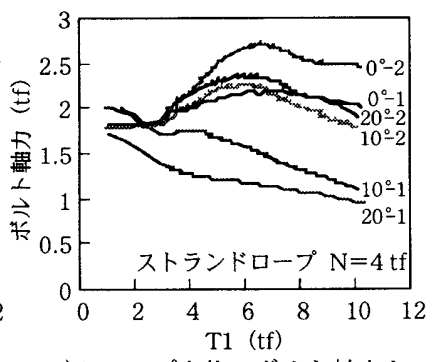

c)クランプ金物のボルト軸力と ケーブル張力（T1）の関倸

図11 クランプの締付カによる 図12 ケーブルの折れ角による 比較 (자ラト $\cdot \theta=0^{\circ}$ )
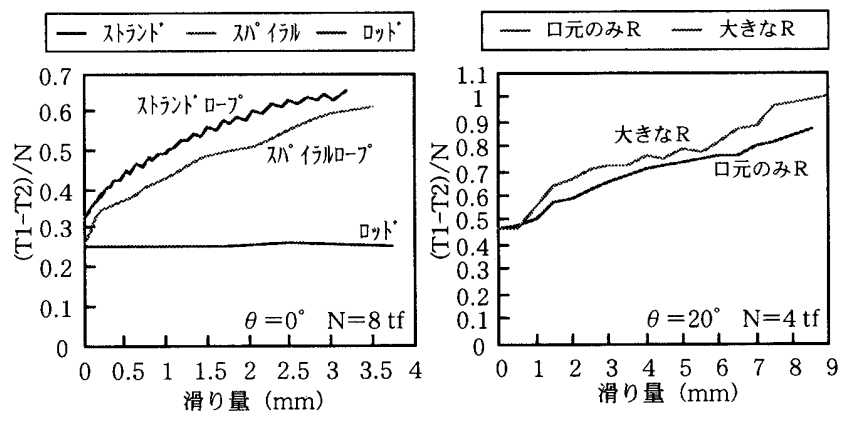

図13 ケーブル種による比較

図14金物の形状による比較

スパイラルで4.5 7.9॰ と求まる。ここで $\alpha$ はケーブルの横圧方向 の剛性Kc之相関関係にあること（図16）と、Kcがケーブルの空隙 係数 $\xi^{2)} \quad($ ストランド $\xi=0.39$ 、スパイラル $\xi=0.24$ ）に関係す ることを考えると、上記 $\alpha 、 \beta$ の值は他の素線構成にも適用可能と 推察できる。なお図16のKcは、ボルト締付カとプレート金物の間 隔の変化量の測定結果（図17・18）より求めたものである。

\section{4 付加荷重実験結果および考察}

図 $19 に \theta=20^{\circ}$ （ストランドロープ）の付加荷重実験結果を、 ボルト軸力の変化に着目して金物形状毎に示す。「大きなR」を有 する金物では、付加荷重の増大に伴うボルト軸力の減少傾向が顕著

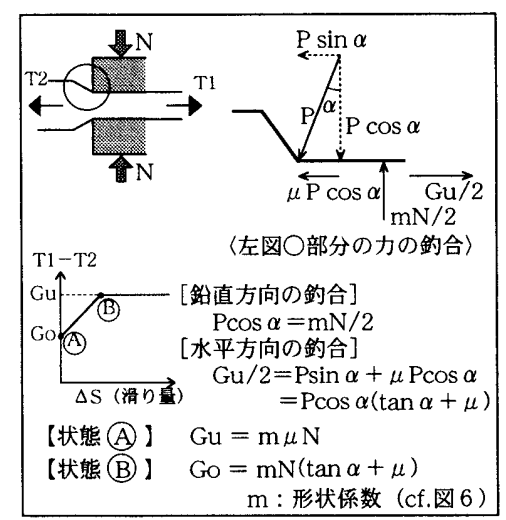

図15 揳効果の評価モテル
表 $2 \beta$ の実測值

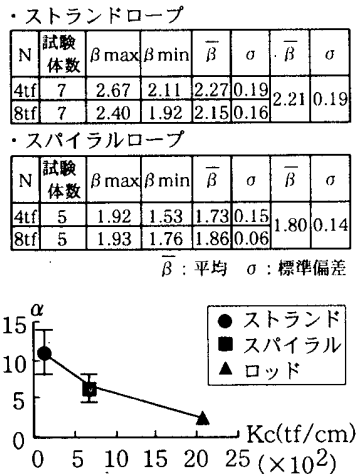

図16 $\alpha-\mathrm{Kc}$ 関係

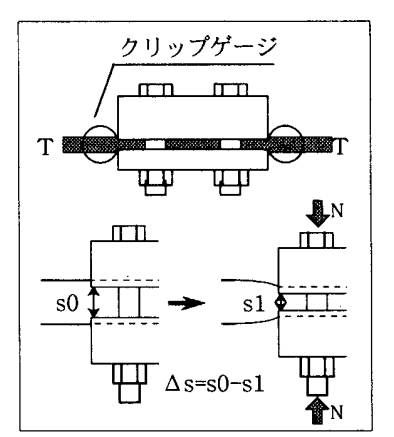

図17 クリップゲージ取付け図

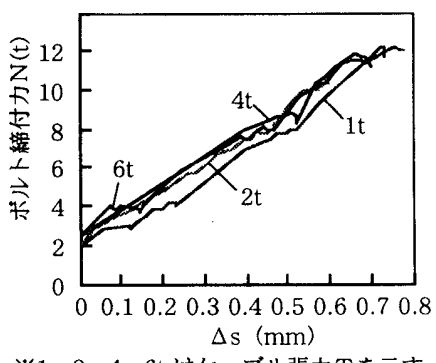

※1、2、4、6tはケーブル張力下を示す。

图18 プレート間変位(s)と ボルト軸力の関係
に現れている。また短期許容引張力（T $1=7.86 \mathrm{tf} ）$ 時のボルト軸 力の初期値に対する割合は、傾斜ケーブル側のボルト軸力（N 1) が約 $40 \%$ 、逆側（N 2 ）が約 $75 \%$ となっておりケーブル張力の減 少に応じた傾向が得られている。一方「口元のみR」のボルト軸力 の減少傾向はボルト位置による差異は見られず、また短期引張力時 のボルト軸力は初期の約 $80 \%$ と減少率も比較的小さい。同様の性 状は、 $\theta=10^{\circ}$ 、スパイラルケーブルの場合にも得られており、 クランプ金物の簡素化を指向した「口元のみR」の金物は、ボルト 軸力の低下率を比較的小さく設定できる可能性があることが把握さ れた。

\section{4. 滑りの発生が構造システムおよびケーフルに及ぼす影暨}

\section{1 構造システムに及ぼす影響}

上述した楔効果は初期骬りの発生後、ある程度の滑りの発生と共 に発揮される。このため楔勃果を考慮した安全率の設定の際には、 滑りの発生が構造システムに及ぼす影響を評価しておく必要がある。

ここでは、張弦梁構造を対象として、滑りの発生が応力・変形に 及ぼす影響について解析的に検討を行う。図20に張弦梁構造を対 象として、束とストリングの交点における不釣合力 $\Delta T^{\prime}$ (滑動力 $\Delta \mathrm{T}$ と把握力Goの差）と、当該部分に生じる滑り量 $\Delta S$ S関係を示 す。また図21はストリングのサグ・スパン比 $(\kappa)$ が一定下（ $=0.08 ） に お け る \Delta \mathrm{T}$ 'と $\Delta \mathrm{S}$ 関係を、束位置（n）をパラメータと して示したものであるが、ケーブルの折れ角が小さいほど滑り量が 小さくなる傾向が得られている。図22に滑り発生後の応力・変形 と滑り量の関係を示す。初期骬り発生後、把握力の增大と共に滑動 力と不釣合力が減少することを勘案すると、曲げモーメントと変位 量の增加量は0.01 0.1\%程度と評価でき、滑りの発生が構造シス テムに及ぼす影響は無視できるオーダーだと考えられる。 


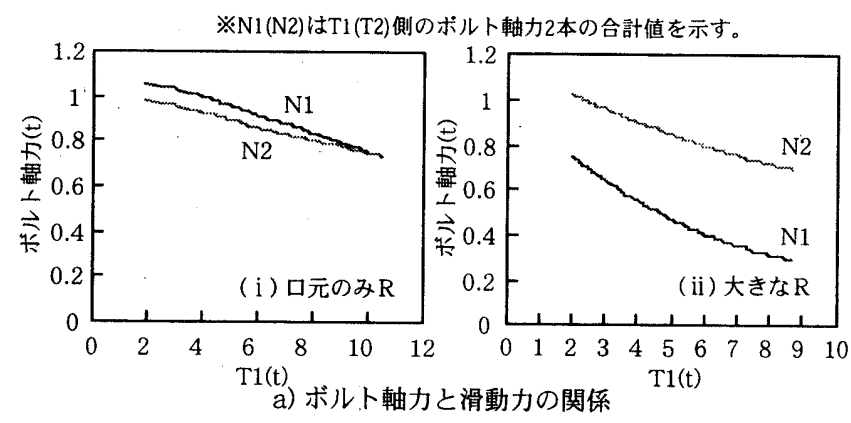

※2,4はT1側ボルト軸力、1,3はT2側の同値を示す。

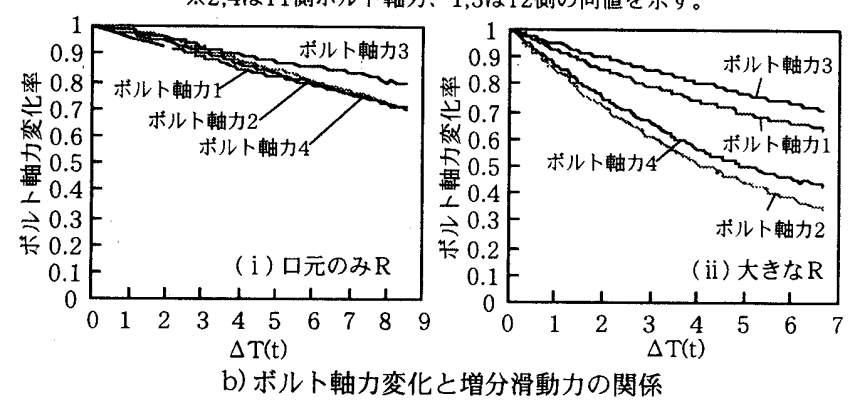

※N1はT1側のボルト軸力 2 本の合計を全ボルト軸力Nで 無次元化した值、N2はT2側の同値を示す。

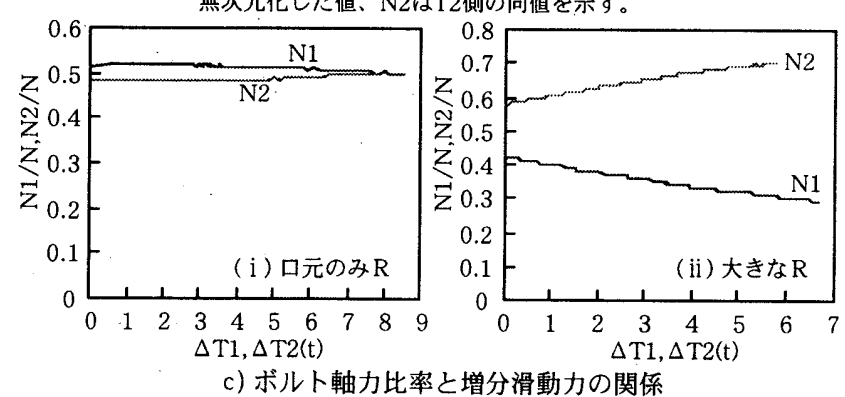

図19付加荷重時のボルト軸力の変化

(ストランドロープ、 $N=4 \mathrm{tf}, \theta=20^{\circ}$ )

\section{2 滑りの発生がケーフルに及ほす影䈉}

滑りの発生がケーブルに及ぼす影響を把握するため、滑動力実験 後のケーブルを用いて、引張疲労試験を行った。平均荷重をケーブ ルの規格破断荷重 $\mathrm{Fb}$ の $1 / 3$ （長期許容值）、荷重振幅を $35 \mathrm{kgf} / \mathrm{mm}^{2}$ (約0.25Fb) と設定した。結果（図23）より、ケーブ ル種や締付力に関わらず、滑り発生部分では切断していない。これ より滑りの発生による疲労強度の低下は無いと評価できる。

\section{5. 許容側圧に関する検討}

「設計施工指針」で標準とされている許容側圧值（図 $24 ※$ 参照） は、実在の吊橋の塔頂サドル部の推定側圧（平行線ストランド）か ら設定されている ${ }^{19)}$ 。ここでは現行の許容值の妥当性を検証する ため、クランプ金物を取り付けた状態で側圧值をパラメータとして、 引張疲労試験と静的引張試験を行った。後者では平均荷重を $\mathrm{Fb} / 3$ 、 荷重振幅 $\Delta \sigma \mathrm{r} 15 、 35 \mathrm{kgf} / \mathrm{mm}^{2}$ と設定した。

疲労試験の結果を図 24 に示す。 $\Delta \sigma \mathrm{r}=35 \mathrm{kgf} / \mathrm{mm}^{2}$ (約 $0.25 \mathrm{Fb}$ ) の場合、クランプ金物の口元で破断していることから側圧の影響が 見られる。しかしケーブルの設計用許容引張力の長短期の差（約 $0.12 \mathrm{Fb})$ と比較すると、実験時の荷重振幅値は過大と考えられる。 一方 $\Delta \sigma \mathrm{r}=15 \mathrm{kgf} / \mathrm{mm}^{2}(0.1 \mathrm{Fb})$ の場合は、側压に関わらず $\mathrm{N}=2$ $\times 10^{6}$ を満足し強度低下は見られない。引張試験ではクランプ金物 の口元で破断している試験体もあるが、いずれも規格以上の破断荷

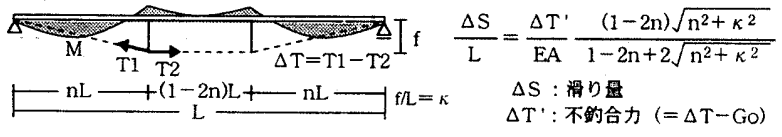

図20 検討モテルと滑り量の一般式

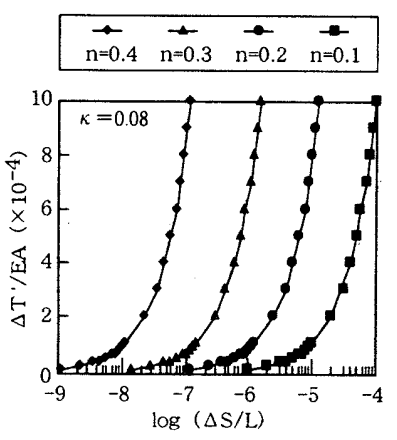

図21 不釣合力一滑り量関係 (解析結果)

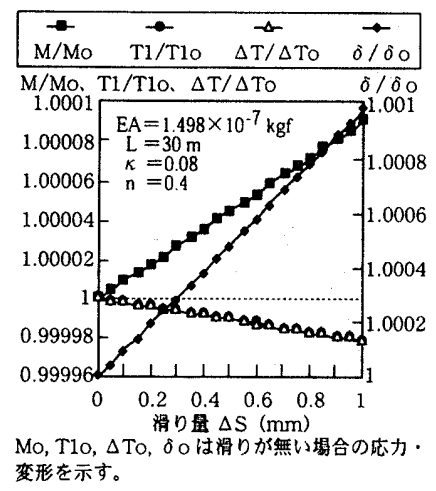

図22

応力・変形一滑り量関係 (解析結果)
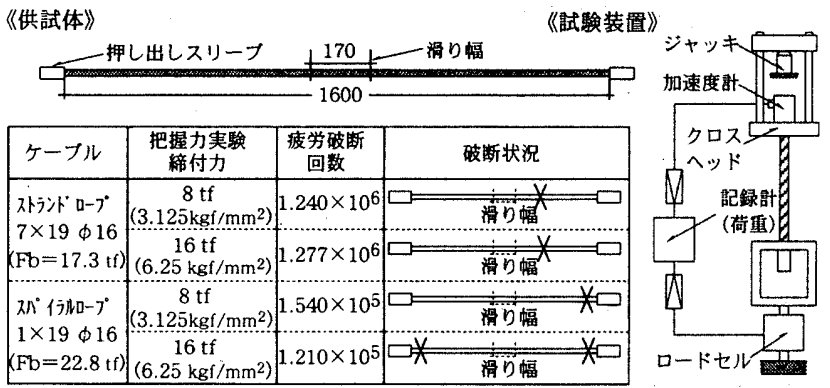

\section{図23引張疲労試験結果（滑りの影䇒考慮）}

《供試体》

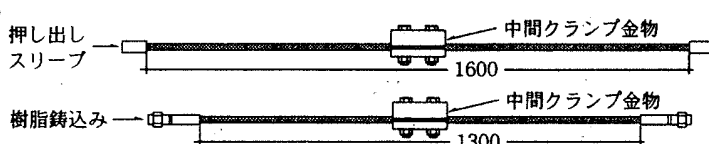

\begin{tabular}{|c|c|c|c|c|c|}
\hline 応力振蝠 & 端末加工 & ケープル & 僋圧 & 疲労破断回数 & 破断状況 \\
\hline \multirow{4}{*}{$\begin{array}{c}35 \\
\mathrm{kgf} / \mathrm{mm}^{2}\end{array}$} & \multirow{4}{*}{$\begin{array}{l}\text { 押し出し } \\
\text { スリーフ }\end{array}$} & \multirow{2}{*}{$\begin{array}{l}\text { 작. } \text { 口-7 } \\
7 \times 19 \phi 16\end{array}$} & $\mathrm{kgf} / \mathrm{mm}^{2}$ & $6.16 \times 10^{4}$ & $\square=x$ \\
\hline & & & 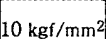 & $2.25 \times 10^{4}$ & $\square$ \\
\hline & & \multirow{2}{*}{$\begin{array}{l}x n^{\circ} 1 \text { 1j月a-7" } \\
1 \times 19 \phi 16\end{array}$} & $6 \mathrm{kgf} / \mathrm{mm}^{2}$ & $6.14 \times 10^{5}$ & $\square=x$ \\
\hline & & & $12 \mathrm{~kg} / \mathrm{mm}^{2}$ & $1.22 \times 10^{5}$ & $\square=0$ \\
\hline \multirow{2}{*}{$\begin{array}{c}15 \\
\mathrm{kgi} / \mathrm{mm}^{2}\end{array}$} & \multirow{2}{*}{ 澍脂 } & \multirow{2}{*}{ 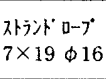 } & $5 \mathrm{kgf} / \mathrm{mm}^{2}$ & 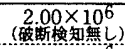 & $\square=$ \\
\hline & & & & 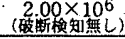 & 口揧泉3本 \\
\hline
\end{tabular}

図24引張疲労試験結果（側圧）

\begin{tabular}{|c|c|c|c|}
\hline \multicolumn{4}{|l|}{ 《供試体》 } \\
\hline ケープル & 側厈 & 破断荷重 /相格破断 & 砖断状呮 \\
\hline \multirow{2}{*}{ 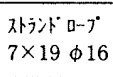 } & $5 \mathrm{kgf} / \mathrm{mm}^{2}$ & $19.4 \mathrm{tf} / 17.3 \mathrm{tf}(=1.121)$ & ケーブル中央全数破断 \\
\hline & $10 \mathrm{~kg} / \mathrm{mm}^{2}$ & $19.2 \mathrm{tf} / 17.3 \mathrm{tf}(=1.110)$ & $\square=x$ \\
\hline \multirow{2}{*}{ 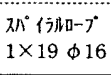 } & $6 \mathrm{kgl} / \mathrm{mm}^{2}$ & $26.0 \mathrm{tf} / 22.8 \mathrm{tf}(=1.140)$ & $\square=\square x$ \\
\hline & $12 \mathrm{kgf} / \mathrm{mm}^{2}$ & $25.9 \mathrm{tf} / 22.8 \mathrm{tf} \quad(=1.136)$ & $\square *=0$ \\
\hline
\end{tabular}

\section{图25静的引張試験結果（側圧}

重を示し、側圧による有意差はない（図25）。以上の結果は少な い試験体から得られたものであるが、現行の許容側圧には、見直す 余地があると考えられる。 


\section{6. ケーブル金物の安全率の設定方法の提案 \\ 6.1 ケープル金物に対する安全率の考え方}

現行の中間クランプ金物の設計法（cf. 図6）では滑りに対する 安全率レとして、長期 3 、短期 2.2 (ケーブルと同值）が標準とさ れている 把握力が初期滑動力の $1.8 \sim 2.5$ 倍に見込めること、滑りの発生がケ一 ブルの強度低下に影響を及ぼさないこと、さらにケーブルのポアソ ン比やクリープによるボルトの締付力の低下は軸力低下係数k（cf. 図6）で別途考虑されていること等を考慮すると、張弦梁構造のよ うに滑り発生が直ちに構造物の耐力の低下に結びつかない構造シス テムに対しては、安全率を小さく設定できる可能性もあろう。

またケーブルの端末金物や定着部はケーブル破断時における弾性 域の保持あるいはケーブルに発生する張力に対する許容值の満足等 を目標として設計されることが一般的である。構造合理性の観点か らは、構造システム全体の安全性を踏まえ、バランスのとれた安全 率の設定が重要であると考える。

ここでは張弦梁構造を対象として、終局状態に着目した中間クラ ンプ金物およびケーブル端末金物の設計法の提案を行い、ケーブル 金物の縮小化と合理化の可能性を示す。

\section{2 張弦梁構造のケーブル金物の必要耐カに関する検討 (1)終局時のケーブル張力}

張弦梁構造を事例として、積雪分布荷重に対する終局状態を算定 し、金物の必要耐力について論じる。算定にあたって一般地域 (ModelA）と多雪地域（ModelB,C）に対して許容応力度設計よ り断面を求めた 3 モデルを設けた。ここでModelBとCの違いは、 変形制限（ $\delta \leqq \mathrm{L} / 300 ）$ の考慮の有無にある（図26）。なお Beamの降伏条件として次式を用いた。

$$
\mathrm{Mpc} / \mathrm{Mp}+(\mathrm{N} / \mathrm{Ny})^{2}=1
$$

図27に検討結果を示す。いずれのモデルもストリングが降伏す る前にBeamが降伏し、図に示す崩壊機構を形成する。なおケーブ ルの破断荷重Fに対する崩填時のケーブル張力は、ModelAで64\%、 Bで $43 \%$ 、Cで65\%となった。

\section{(2)中間クランプ金物の必要耐カの検討}

ここで(1)の事例を対象として中間クランプ金物の把握力に関する 必要耐力を求めてみる。検討条件を以下に示す。

(1)想定荷重下の滑動力の最大値 $\Delta \mathrm{Td}$ （長短期共）に対して初期

把握力Goで抵抗する（ $\nu \Delta \mathrm{Td} \leqq \mathrm{Go} ; \nu$ : 安全率）。

(2)構造体の終局時の滑動力 $\Delta$ Tuに対して、楔効果を考慮した把

握力Guで抵抗する $(\Delta \mathrm{Tu} \leqq \mathrm{Gu} ; \mathrm{Gu}=\beta \mathrm{Go})$ 。

$\nu=1 、 \beta=2$ とした場合、 2 条件を共に満足する中間クランプ 金物の必要把旺力を各Modelに対して求め、従来設計の結果 ([ ]内 の数值）と比較すると、次のようになる（図28）。

\begin{tabular}{c|c|c}
\hline Model & $\mathrm{Go} / \Delta \mathrm{Td}$ & $\mathrm{Gu} / \Delta \mathrm{Tu}$ \\
\hline $\mathrm{A}$ & $1[2.22]$ & $1.2[2.67]$ \\
\hline $\mathrm{B}$ & $1.03[2.45]$ & $1[2.38]$ \\
\hline $\mathrm{C}$ & $1.03[2.38]$ & $1[2.45]$ \\
\hline
\end{tabular}

(3)ケーブル端末金物の必要耐カ

現行のケーブル端末金物は、次の 2 種類の立場で設計されること が一般的である。

(1)ケーブルが破断荷重時に、金物が弾性を保持する。

(2)ケーブルの存在張力に対して許容応力度設計を行う。

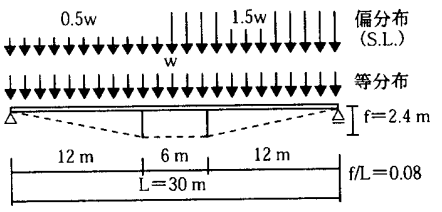

[設計条件］フレームピッチ：5m

\begin{tabular}{|l|c|c|}
\hline & Model A & Model B,C \\
\hline D.L. & $\begin{array}{c}\text { 自重+ } \\
140 \mathrm{kgf} / \mathrm{m}^{2}\end{array}$ & $\begin{array}{c}\text { 自重 }+ \\
140 \mathrm{kgf} / \mathrm{m}^{2}\end{array}$ \\
\hline S.L. & $60 \mathrm{kgf} / \mathrm{m}^{2}$ & $500 \mathrm{kgf} / \mathrm{m}^{2}$ \\
\hline 長期 & D.L. & D.L. +0.7 S.L. \\
\hline 短期 & D.L. + S.L. & D.L. + S.L. \\
\hline
\end{tabular}

・許容変位： $\delta \leqq \mathrm{L} / 300$ (付加荷重時) $\Rightarrow$ 常持荷重時に正負のMが等しくなるようにPSを設定 [構造諸元、検定值］・常特荷重時に正負のMが等しくなるようにPSを設

\begin{tabular}{|c|c|c|c|c|}
\hline & Beam & String & Strut & 変形量 \\
\hline \multirow[b]{2}{*}{ Model A } & H- $340 \times 250 \times 9 \times 14$ & $1 \times 61 \phi 40 \cdots 1$ 本 & $\phi 76.3 \times 4.0$ & \\
\hline & $\begin{array}{c}\text { D.L. }+ \text { S.L (偏) } \\
\sigma \mathrm{b} / \mathrm{fb}+\sigma \mathrm{c} / \mathrm{fc}=1.000\end{array}$ & $\begin{array}{c}\text { D.L. } \\
\mathrm{T} / \mathrm{Fb} / 3=0.854\end{array}$ & $\begin{array}{c}\text { D.L. } \\
\sigma \mathrm{c} / \mathrm{fC}=0.908\end{array}$ & $\begin{array}{l}\text { D.L. }+ \text { S.L (偏) } \\
\delta / \mathrm{L} / 300=0.906\end{array}$ \\
\hline \multirow{2}{*}{ Model B } & H- $912 \times 302 \times 18 \times 34$ & $1 \times 127 \phi 60 \cdots 2$ 本 & $\phi 114.3 \times 5.6$ & \\
\hline & $\begin{array}{c}\text { D.L. }+0.7 \mathrm{~S} . \mathrm{L} \text { (偏) } \\
\sigma \mathrm{b} / \mathrm{fb}+\sigma \mathrm{c} / \mathrm{fc}=0.773 \\
\end{array}$ & $\begin{array}{c}\text { D.L. +0.7S.L } \\
\mathrm{T} / \mathrm{Fb} / 3=0.507 \\
\end{array}$ & $\begin{array}{l}\text { D.L. }+0.7 \mathrm{~S} . \mathrm{L} \\
\sigma \mathrm{c} / \mathrm{fc}=0.850\end{array}$ & $\begin{array}{l}\text { D.L + S.L (偏) } \\
\delta / \mathrm{L} / 300=1.000\end{array}$ \\
\hline \multirow[b]{2}{*}{ Model C } & $\mathrm{H}-900 \times 300 \times 16 \times 28$ & $1 \times 61 \phi 45 \cdots 2$ 本 & $\phi 114.3 \times 5.6$ & \\
\hline & $\begin{array}{c}\text { D.L. }+0.7 \mathrm{~S} . \mathrm{L}(\text { (偏) } \\
\sigma \mathrm{b} / \mathrm{fb}+\sigma \mathrm{c} / \mathrm{fc}=0.975\end{array}$ & $\begin{array}{c}\text { D.L. }+0.7 \mathrm{~S} . \mathrm{L} \\
\mathrm{T} / \mathrm{Fb} / 3=0.819\end{array}$ & $\begin{array}{l}\text { D.L. }+0.7 \mathrm{~S} . \mathrm{L} \\
\sigma \mathrm{c} / \mathrm{fc}=0.808\end{array}$ & $\begin{array}{l}\text { D.L. +S.L. (偏) } \\
\delta / \mathrm{L} / 300=1.450\end{array}$ \\
\hline
\end{tabular}

図26 解析モデル
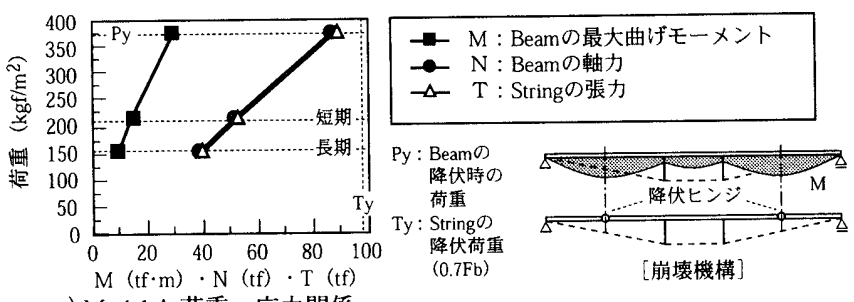

a) Model A 荷重一応力関係

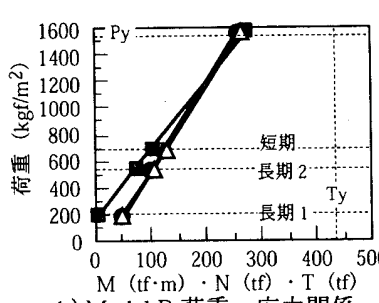
【Model A】けねはGoを示す。は玩行の設計法にお

\begin{tabular}{|c|c|c|c|}
\hline & $\Delta \mathrm{T}$ & $\Delta \mathrm{T} \times$ 安全率 & 終局時の $\Delta \mathrm{T}$ \\
\hline 長期 & $0.774 \mathrm{tf}$ & $2.323 \mathrm{tf} *$ & \multirow{2}{*}{$1.739 \mathrm{tf}$} \\
\hline 短期 & $\langle 1.046 \mathrm{tf}\rangle$ & $2.298 \mathrm{tf}$ & \\
\hline \multicolumn{4}{|c|}{ 【Model B】 } \\
\hline & $\Delta \mathrm{T}$ & $\Delta T \times$ 安全率 & 終局時の $\Delta \mathrm{T}$ \\
\hline 長期 1 & $0.979 \mathrm{tf}$ & $2.936 \mathrm{tf}$ & \multirow{3}{*}{$5.191 \mathrm{tf}$} \\
\hline 長期 2 & $2.056 \mathrm{tf}$ & $6.169 \mathrm{ff} *$ & \\
\hline 短期 & $\langle 2.518 \mathrm{tf}\rangle$ & $5.539 \mathrm{tf}$ & \\
\hline
\end{tabular}

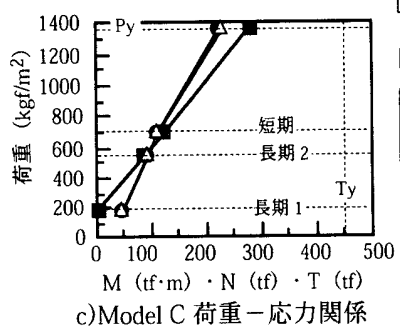

[ModelC】

\begin{tabular}{|c|c|c|c|}
\hline & $\Delta \mathrm{T}$ & $\Delta \mathrm{T} \times$ 安全率 & 終局時の $\Delta \mathrm{T}$ \\
\hline 長期 1 & $0.934 \mathrm{tf}$ & $2.802 \mathrm{tf}$ & \\
長期 2 & $1.846 \mathrm{tf}$ & $5.538 \mathrm{tf} *$ & $4.526 \mathrm{tf}$ \\
\hdashline 短期 & $\langle 2.196 \mathrm{tf}\rangle$ & $4.831 \mathrm{tf}$ & \\
\hline \multicolumn{4}{|c|}{ ·長期 1 $:$ D.L.. 長期 2 $:$ D.L. + 0.7S.L. } \\
·安全率 : 長期 3、短期 2.2
\end{tabular}

d) 中間金物の安全率と終局強度

\section{図27解析結果}

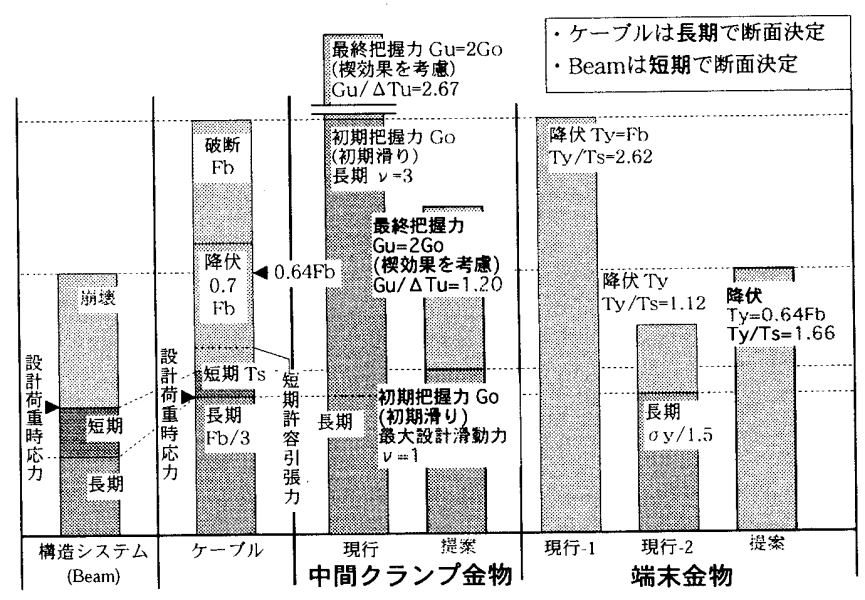

図28 ケーブル金物の必要耐力の算定例（Model A : 一般地域） 
これらは、主にケーブルで構成された構造システムあるいは、剛 性確保の観点から断面を割增したケーブルに対して、合理的な解を 得ようとする考えである。しかし、張弦梁構造のように剛な部材と ケーブルを組み合わせた構造システムでは、ケーブルより先に剛な 部材が降状することが多いため、終局強度の観点からは幾分合理性 に欠ける場合もある。

以上の観点から、構造システムの終局状態に、ケーブル端末金物 が降伏軸力Pyに達するとの条件下で、金物の必要耐力を求めてみ る。すなわち、終局荷重におけるストリング張力を端末金物の降伏 軸力Pyに等置すると、Pyと最大発生張力Tsの比は以下のようにな る（cf.図28、[]内の数値は従来の設計(1)の場合）。

\begin{tabular}{c|c}
\hline Model & $\mathrm{Py} / \mathrm{Ts}$ \\
\hline $\mathrm{A}$ & $1.66[2.62]$ \\
\hline $\mathrm{B}$ & $2.06[4.84]$ \\
\hline $\mathrm{C}$ & $2.00[3.05]$ \\
\hline
\end{tabular}

上記(2)(3)の検討は一例について行った結果に過ぎないが、ケーブ ル金物を終局時の応力に基づいて設計することにより、安全性を保 持しながら、合理的に金物を縮小化できる可能性があることが示唆 された。

\section{7. まとめ}

本論では中間クランプ金物の把握力の評価実験、疲労試験、引張 試験および数值解析で得られた性能に基づいて、終局状態に着目し た中間クランプ金物とケーブル端末金物の適正な安全率の設定に関 する検討を行い、金物の縮小化・簡素化の可能性を示した。検討の 結果得られた新しい知見を以下に示す。

(1)滑動試験の結果、ケーブルの初期滑りの発生後、把握力が大き くなる性状が得られた。これはケーブルの締付部分と非締付部 分の径の差に起因する「楔効果」によるものと評価できる。さ らに楔効果は、ケーブルの横圧方向の剛性やケーブルの空隙係 数と関係する傾向があることを示した。

(2)中間クランプ部におけるケーブルの折れ角が大きくなるに従っ て、把握力が大きくなる傾向が得られた。これは束の存在圧縮 力に起因する摩擦力の効果と評価される。

(3)ケーブルが金物から出る部分のみ潅部を曲面加工した「口元の みR」の金物は、把握力やボルト軸力の低下等に関して中間ク ランプ金物として十分適用可能な性能を有している。

(4)滑動試験後のケーブルを使用した引張疲労試験の結果、滑りの 発生が疲労強度の低下に及ぼす影響は認められなかった。

(5)許容側圧の 2 倍まで締め付けた状態で、引張疲労試験と静的引 張試験を実施した結果、ケーブルの耐力の低下は見られなかっ た。このことより、許容側圧值の見直しの必要性が示唆された。 (6)張弦梁構造のみを対象とした検討ではあるが、滑りの発生が直 ちに構造システムの性能低下には結びつかないことを、数值解 析により示した。このことから、構造システムによっては、滑 りに対する安全率を小さく設定できる可能性を示した。

(7)張弦梁構造を一例として、ケーブル金物を終局時の応力に基づ いて設計することにより、合理的に金物を縮小化できる可能性 があることを示した。

(8)以上の結果より、中間クランプ金物の設計時における必要把握
力Goは、滑動力 $\Delta \mathrm{T}$ に、滑りの発生が構造システムの性能低 下に及ぼす影響や終局状態の応力を勘案した安全率レと、ケー ブルの折れ角による存在摩擦力を考慮した係数を、乗じたもの で評価できると考える。

今後さらにケーブル金物の設計法を充実させるためには以下の検 討が必要であると考える。

(1)各種ケーブル（素線構成の種類、被覆の有無と種類、径）やプ レート（材種、表面処理法）の組合せに対する、横圧方向の剛 性や楔効果などの材料デー夕の蓄積や信頼性の向上、及び揳効 果の推定式の妥当性の検証。

(2)許容側圧の適正な設定のための材料データの収集。 (3)滑りの発生が各種構造システムに及ぼす影響度の把握。

\section{謝辞}

本研究を遂行するにあたり、供試体の製作および疲労・引張実験 の実施面で御協力を頂いた神鋼鋼線工業（株）の関係者に、また把 握力の実験の実施と本論の作成に御尽力頂いた日本大学大学院 竹 川正慶君（現 西松建設（株））に謝意を表します。

\section{【参考文献】}

1）日本鋼構造協会：建築構造ケーブル設計施工指針，1983

2) 日本建筑学会 : ケーブル構造設計指針・同解説, 1994

3) M. Saitoh : Principle of Beam String Structure, Proc. of IASS (Madrid) vol.4, pp.17〜38, 1979

4) 斎藤公男・岡田 章 : 建築におけるケーブル構造の課題と展開, 鋼構 造論文集第 1 巻 3 号, $1994 \cdot 9$

5）斎藤公男・岡田 章他：点支持方式のガラス・ファサードの力学特性 に関する基礎的研究（その2），日本建築学会学術講演梗嘅集， pp. $747 \sim 748,1995$

6）斎藤公男監修：透明なデザインと建策技術，建築技術，1996・1

7) M. Saitoh and A. Okada : From Image to Technology - The Role of String in Hybrid String Structures -, Proc. of IASS (Stuttgart) vol.2, pp.663 670, 1996

8）斎藤公男・岡田 章：ストリング式骨組架構（SKELSION）の構造概 念と力学特性について，銅構造論文集第 1 巻 3 号, $1994 \cdot 9$

9）例えば、日本道路協会：道路橋示方書, 1990

10）例えば、本州四国連絡橋ケーブルバンド設計要領（案），本州四国連 絡橋公団, 1978

11）斎藤公男・岡田 章他：多雪地域におけるストリング式骨組架構 (SKELSION) の適用，日本建築学会学術講演梗概集，pp.849 850, 1996

12）斎藤公男・岡田 章他：多雪地域における木造複合張弦梁構造の構造 特性に関する研究（その1）（その2），日本建築学会学術講演梗概 集, pp.851 854, 1996

13）斎藤公男・岡田 章他：ファサードに用いるテンセグリック・トラス の力学特性に関する研究（その1）（その2），日本建築学会学術講 演梗概集，pp.1035 1038，1998

14）斎藤公男・岡田 章他：ケーブル金物の設計法に関する基䃈的研究 （その1），日本建築学会学術講演梗概集，pp.1019～1020，1998

15）斎藤公男・岡田 章他：ケーブル金物の設計法に関する基礎的研究 （その 2），日本建策学会学術講演梗概集， pp.1021 1022，1998

16）斎藤公男・岡田 章他：ケーブル金物の設計法に関する基礎的研究 （その 3 ），日本建築学会学術講演梗概集，pp.1023 1024, 1998

17）文献 1)，p.27、文献 2)，pp.92 93

18）文献 2）, pp.91 100

19) 文献 1), p.26

20）文献 2) , p.106 